PROCEEDINGS OF THE SOCIETY OF MEDICAL OFFICIRS OF HEALTH.

HOUNDED I856. RECONSTRUC'AD I888. INCORPORATED I 892 .

\section{PROVINCIAL MEETING.}

THF Annual Provincial Meeting of the Society was held on Saturday, 29th June, I9I8, and was attended by the undermentioned Fellows :Dr. Chas, Sanders, President (in the chair), Drs. G. F. Buchan, F. Foord Caiger, J. J. Clarke, R. Veitch Clark, W. M. Clendinnen, G. H. Dupont, R. J. Ewart, W. Gruggen, H. W. Harding, J. S. Higgins, Col. J. R. Kaye, S. C. Lawrence, Capt. F. C. Linton, Bertram Smith, Major J. S. Tew, Mr. W. W. Whitaker, and the following visitors :Dr. J. McD. Borland, W. de V. Monis, Esq., J. G. Morley, Esq., and Capt. Fi. P. Wheeler.

The company met at Ir.30 a.m. in the Hamilton Hall of the Abercorn Rooms, Bishopsgate, for the transaction of business and on the suggestion of the President it was resolved that he also undertake the duty of Acting Secretary.

The Minutes of the Provincial Meeting held on 3oth June, Igr7, printed in PUBLIC HEALTH (August, rgry), were taken as read and duly confirmed.

Letters of regret for inability to attend were received from Professor Kenwood (Presidentelect), Dr. John Robertson, C.M.G., O.B.E. (exPresident), Professor R. Bostock Hill (Treasurer), Dr. Brownlee, and several other Fellows.

The following persons were duly nominated for election as Fellows:-Dr. Madeline S. Baker, Dr. Gilbert Bailey, and Dr. Cyril Augustus Paulusz.

The two undermentioned candidates, who had been duly nominated, were ballotted for, and declared elected Fellows of the Society :-

LEIGH, J. DICKINSON, M.D., F.R.C.S.(Edin.), D.P.H., 9, Rectory Terrace, Sunderland, Tuberculosis M.O., Studerland, C.B.

NIEL, ELIZABETH, M.D., B.S., B.Hy., D.P.H., 4. Park Terrace, Sunderland, Tuberculosis M.O., Northumberland Coy,

In the unavoidable absence of the writers, the following notes on recent outbreaks of disease simulating Botulism, submitted respectively by Dr. Benton, of East Ham, and Dr. W. G. Savage, of Somerset, were read.

NOTES ON RECENT CASES OF EPIDEMIC ENCEPHALITIS SIMULATING " BOTULISM."

BY

DR. WM. BENTION; Medical Officer of Health of East Ham.

$D^{\mathrm{t}}$ URING the past two months I have had eight cases under observation, which showed clinical symptoms of "Botulism," although on investigation of the cases I could find nothing that led me to think that the Bacillus Botulinus was the cause of the mysterious disease. Four of the cases proved fatal.

The first cases were those of a woman aged 30 years and a man aged 45 years, who were sent into my Isolation Hospital as suffering from typhoid fever.

In each case the patients had been ill for fourteen days previously, and their condition in the absence of any other diagnosis was thought by the practitioners to be that of typhoid.

Case No. I. The woman was admitted on April 27 th, with a history of being first taken ill with a feeling of sickness and headache. On admission the patient was drowsy, lips and tongue dry, causing a difficulty in swallowing, marked delirium, ptosis and double vision, constipation, temperature Ioo, pulse 96. After the first two days the temperature dropped, and never rose to more than 99.2. Reflexes were normal. There was no history of the patient having partaken of any food that might have caused the illness. The patient was in the hospital six weeks, and at the time of discharge still complained of "weak feeling down the spine" and had difficulty in rising from the bed or chair.

Case No. 2. Male, aged 45 years. Admitted on April 3oth. He first fell ill on April r4th, and complained of headache and a few days later, when taken to see his medical man, complained of dotrble vision and difficulty in opening the eyelids. The patient went to bed, became very drowsy, and delirious. $\mathrm{He}$ was notified as suffering from typhoid, and admitted to hospital on April 3oth. His temperature on admission was normal, pulse Ioo, and respiration 24 . He was very drowsy, but could easily be awakened, and talked quite sensibly, but after talking a few minutes would sleep again and become delirious. There was marked ptosis, squint and diplopia. The moth and tongue were very dry, and there was much difficulty in swallowing. The patient remained in this condition tutil May 16 th, when he died from heart failure, the temperature rising to $103^{\circ}$ just before death occurred.

A few days after these cases were admitted, I wrote to each medical man in the borough describing the symptoms and asking to be informed of any similar cases in order that I might try to discover the origin of the disease and find out if this might be traced to any food the patients had taken in common. I was asked to see two cases in consultation with medical men the next day.

Case No. 3. Married woman, aged 37 years. The patient had been ill with headache, drowsiness, ptosis, diplopia, etc., for the three weeks previous to the day I saw the patient. As the medical man in attendance could not diagnose the case, a consultant was called in who said that he also could not make a diagnosis, but thought it must be tubercular meningitis. When I saw the patient, the condition had improved, and later one of the 
medical inspectors of the Local Government Board also visited the case, and agreed with tny diagnosis, and both gave a favourable prognosis. The patient gradually improved until May 26th, when she died quite suddenly, after sitting up in the bedroom.

Case No. 4. A youth aged I7 years. Had been ill ro days with " headache and tight feeling in the chest." The day I visited the case he had marked ptosis, squint, stupor, with delirium and difficulty in swallowing. This patient has slowly recovered, but still has some ptosis and squint.

Case No. 5. Married woman, aged 37 years. I was asked to see the patient by the medical man in attendance on May $3 \mathrm{rd}$. The history was that the patient had been ill for about a fortnight with severe headache and pain in the back of the neck. The patient was then very drowsy, delirious, with ptosis, and inability to swallow. She was admitted to hospital on May $4^{\text {th }}$, and died on May 6 th, the temperature rising to Io $^{\circ}$

Case No. 6. Youth aged I8 years. Came to my office and told me that he had been in bed for a fortnight with headache, and as his eyes became affected he was advised by his panel doctor to go to an ophthalmic hospital for advice. The ophthalmic surgeon who saw the youth told him that it was not a case for treatment there, and advised him to come and see me. The patient was brought by his mother, and when I saw him he had matked ptosis with squint. He still has, after six weeks, drooping of the left eyelid with squint.

Case No. 7. Girl aged 9 years. I was asked to see this patient on May 3 rd in consultation. The first symptoms appeared on April 3oth; the child was out with her mother and complained of a headache with double vision. I saw the patient at Io p.m. on May 5th. She then had marked ptosis, squint, and was very drowsy, but spoke to me when I asked questions. She had during the day expressed a wish that I might see her, as a few months previously she had been under my care at the hospital. I visited the patient again on May 6 th with the medical inspector of the local Government Board, when the symptoms were more marked, and the patient died next day.

Case No. 8. Girl aged 18 years. Taken ill on May 2nd, the first symptom being pain in the back of the head and neck with drowsiness. The patient was admitted to the hospital at the request of medical practitioner on May $9^{\text {th. }}$. On admission the patient was delirious and drowsy, but easily awakened. The temperature was normal, but rose during the day to $100^{\circ}$. Pulse was 78 and respiration 22. There was ptosis, but no diplopia or squint. Reflexes were normal. The patient took her discharge on May 2oth. She was sent home by ambulance, and is still confined to bed.

In each case there was marked constipation, two suffered from incontinence of urine, and one from retention, The difficulty in swallowing appeared to be due to the dry condition of the tongue and throat from diminished saliva.

Fxamination of the blood and cerebro-spinal fluid of the cases treated in the hospital gave negative results.

Post-mortem on three Cases. -There were no signs of inflammation of the meninges. There was congestion of the surface of the medulla and pons, but no signs of any pus formation. The medulla on sections appeared normal to the naked eye. All other organs were normal.

Having these eight cases within a few weeks suggested an epidemic, but the patients came from entirely separate parts of the borough, and no second case occurred in the same house.

The disease resembled the symptoms of "Botulism" as given by Muir and Ritchie, but in no case could the illness be traced to any food that had been taken.

In the case of the child aged 9 years the mother suspected tinned salmon which the child had partaken, but none of the other members of the family had suffered in any way.

Examination of another tin of salmon of the same brand and purchased at the same time gave negative results.

I have not seen or heard of any fresh cases since the beginning of May, and have no evidence to offer as to the etiology of these cases.

NoTes BY DR. W. G. SAVAGE (SOMERSET C.M.O.H.) were read as follows:-

I have read a good many of the descriptions of the recorded cases of so-called Botulism which have occurred recently, and I do not think they furnish sufficient justification for ascribing them to this disease. It is true that in both conditions many of the symptoms seem to be referable to lesions of the cerebral nerves, but obviously this is a condition which may be set up by a number of different agencies. The best account of the symptoms of Botulism is contained in Van Ermengem's Monograph (Kolle \& Wasserman Handbuch der Pathogenen Mikrorg, Igr2, Vol. IV., page gog), and it may be of interest to give a brief summary of the essential symptoms of this disease which I have taken from this report, supplemented by a study of the original papers of individual outbreaks reported by Römer, Fischer, Schumacher, Wilbur and Ophuls, Schede, etc.

The symptoms shown are almost entirely referable to lesions of the central nervous system. Prominent symptoms are those referable to disturbance of the throat, digestive tract, such as thirst, feeling of constriction of the throat, dysphagia, skin-like coating of mouth and pharynx, complete loss of appetite, obstinate constipation-and octlar symptoms-such as internal or external and more or less complete opthalmopolegia, paralysis of accommodation, mydriasis, nystagmus, internal stabismus. Other symptoms which may be met 
with are diuresis, or complete anuria, complete loss of voice, prolapse, or paresis of the tongue.

The fatal cases show gradually advancing respiratory and cardiac failure due to progressive bulbar paralysis. Vomiting and diarrhoea are frequently absent, but may occur, and if present are usually slight or transitory. Fever is never observed, muscular cramps do not occur, consciousness is not impaired.

The ocular symptoms usually develop in a progressive order. Amaurosis first occurs, then more or less complete accommodation paralysis frequently followed by ptosis, mydriasis, diplopia, etc. In cases which recover these ocular symptoms may last for many weeks.

It will be noted that while there are many symptoms common to Botulism and the English cases, there are many differences of material importance. The absence of fever in Botulism is important, since the report issued by the Local Government Board states that in about half the cases which have recently occurred, pyrexia was present. As a rule in Botulism the onset is more or less sudden, and the symptoms are acute from the first.

Apart from the question of symptoms, the grouping of the cases is quite unlike botulism. This disease is due to $B$. botwlinus, a pathogenic saprophyte which does not invade the tissues but grows as a strict anærobe under favourable conditions upon food or other suitable nutrient material, and there produces its toxins. Living animals are not infected with $B$. botulinus, but it grows from an invasion of dead animal or vegetable tisstle. In nearly every case not only has the food been kept for a long time, but it has been eaten without being again cooked. The symptoms are due to a true ectotoxin which is destroyed by efficient cooking. To get an outbreak we have to postulate three conditions, infection of the food with $B$. botulinits, the existence after infection of true anzrobic conditions which will favour. its multiplication and toxin formation, and either no cooking of the food before consumption or so efficient that the not highly resistant toxins escape destruction. Where such conditions do occur, it is almost certain that the food will be such as to be eaten by more than one person, and groups of cases will arise with a common origin and with onsets close together. From these considerations it follows that isolated sporadic cases must be almost unknown, while there is no question of case to case infection since infection is due to a toxin and not to general bacillary infection.

To suggest, therefore, as I believe has been done, that the present series of cases are examples of botulism due to widespread infection from tinned meat, is a conclusion which available information hardly fails to justify, which would not be advanced without more definite facts by anyone actually cognizant of the nature of botulism, and particularly its bacteriology and epidemiology.

An account of the symptoms, epidemiology, etc., of this disease is given (page 27 and 29) in $m y$ report on food poisoning and food infection to the Local Government Board (Igr3), and I there point out that up to that time I was unable to trace the occurrence of a single outbreak in Great Britain.

The present series of cases, so far as I have been able to study them in the various reports, show no association into groups with a sudden onset and a common cause, do not appear to be associated with any one common article of food, and do not appear to be associated with the presence of $B$. botulinus. Unless far more convincing evidence than has been reported is advanced, I fail to see why the term botulism has been imported into the business.

I trust these notes from the food poisoning point of view will be of interest.

W. G. SAVAGE.

On conclusion of business, the company partook of luncheon, at the invitation of the President in the adjoining Reception Room, and at r.30 p.m. took train to Silvertown, where, by permission of C. R. S. Kirkpatrick, Engineer to the Port of London Authority, they were shown the new South Albert Dock, now in course of construction, together with some interesting geological finds unearthed during the excavation, and subsequently were conducted over the latest Cold Storage Installation abutting on the North Albert Dock. The fine weather lent an additional charm to the extensive view of the surrounding parts of Kent, Surrey, Middlesex, and Essex obtainable from the top of this building, reaching from Shooter's Hill to Epping Forest, and from St. Paul's Cathedral to Havering-atte-Bower.

At 3.55 p.m. the party visited the London School of Tropical Medicine attached to the Albert Dock (Branch Seamen's) Hospital, where they were received by Colonel A. Alcock, C.I.E., F.R.S., and Dr. R. P. Cockin, were entertained with the creature comforts of a very welcome tea, and were then provided with an intellectual treat in the museum and laboratory of the School. The valuable microscopical display of infective human parasites, bacillary, and protozoal, with descriptive drawings carefully prepared by Colonel Alcock, was particularly appreciated, and the President was requested to convey on behalf of the Fellows of the Society their heartiest thanks to the gentlemen named for so generously affording them an interesting and instructive afternoon.

WHEN MOSES WAS BOARDED OUT.-At the recent Conference in London on Baby Week, Dr. Harold Scurfield, Medical Officer of Health of Sheffield, advocated pensions for mothers. In the course of his remarks he pointed out that the first pension was awarded when Moses was boarded out with his own mother. Then Pharaoh's daughter paid the pension. 